"Microfinance banks and small and medium sized enterprises access to finance: the Nigerian experience"

\begin{tabular}{|c|c|}
\hline AUTHORS & $\begin{array}{l}\text { Lawrence Ogechukwu Obokoh } \\
\text { James Unam Monday } \\
\text { Udechukwu Ojiako }\end{array}$ \\
\hline ARTICLE INFO & $\begin{array}{l}\text { Lawrence Ogechukwu Obokoh, James Unam Monday and Udechukwu Ojiako } \\
\text { (2016). Microfinance banks and small and medium sized enterprises access to } \\
\text { finance: the Nigerian experience. Banks and Bank Systems, 11(4-1), 111-121. } \\
\text { doi:10.21511/bbs.11(4-1).2016.01 }\end{array}$ \\
\hline DOI & http://dx.doi.org/10.21511/bbs.11(4-1).2016.01 \\
\hline RELEASED ON & Thursday, 22 December 2016 \\
\hline JOURNAL & "Banks and Bank Systems" \\
\hline FOUNDER & LLC "Consulting Publishing Company "Business Perspectives" \\
\hline
\end{tabular}

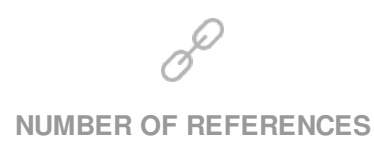

0

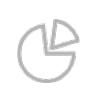

NUMBER OF FIGURES

0

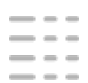

NUMBER OF TABLES

0

(C) The author(s) 2022. This publication is an open access article. 


\title{
Microfinance banks and small and medium sized enterprises access to finance: the Nigerian experience
}

\begin{abstract}
The paper explored the extent to which current microfinance lending impacts on indigenous SME access to finance and how the intermediation services of the microfinance banks (MFBs) contributed to or otherwise to the development of SMEs. A total of 800 such indigenous SMEs were identified, however, data were obtained from 300 of the identified indigenous SMEs from a questionnaire survey in four states (provinces) within the country that make up the Niger Delta region. The result shows positive contribution of microfinance lending to the development of such enterprises. However, it appears that a number of factors including cumbersome process, poorly packaged business plans and perceived high cost of credit still limit the access of indigenous SMEs to credit.
\end{abstract}

Keywords: microfinance banks, SMEs, entrepreneurship, financial services.

JEL Classification: G21, L26, M13.

\section{Introduction}

Small and medium sized enterprises (SMEs) play a critical role in sustainable economic development of many nations, because it has been identified as a catalyst for economic growth and development in both emerging and developed economies of the world (Normah, 2007; Obokoh, 2008, p. 92). Some scholars believe that entrepreneurship has a critical role in the achievement of the United Nations blueprint on Millennium Development Goals (Shkolnikov and Sullivan, 2010; Alvarez and Barney, 2014). Thus, the need for apt development of the sector cannot be overemphasized, as it has the ability to stimulate ingenious entrepreneurship, create jobs, mobilize raw materials and semi-processed products as inputs for large-scale enterprises besides its contribution to the gross domestic products (GDPs) of many countries (Udechukwu, 2003). SMEs are less capital intensive and have the flexibility to respond quickly to fluctuating demands of the market due to their size and innovativeness (Obokoh, 2011, p. 338). In addition, SMEs sector also serves as incubator for new ideas and testing ground for new technologies (Oyefuga et al., 2008, p. 234).

Despite the critical role of SMEs in the economies of developing countries, they are plagued by small capital base, worsened by the high cost and difficulty to obtain funding from commercial banks (Obokoh, 2008, p. 94; Ngehnevu and Nembo, 2010; Sriram and Mersha, 2010, p. 258). It has been observed that commercial banks traditionally prefer to

(C) Lawrence Ogechukwu Obokoh, James Unam Monday, Udechukwu Ojiako, 2016.

Lawrence Ogechukwu Obokoh, Professor, Department of Cost and Management Accounting, Cape Peninsula University of Technology, Cape Town Campus, South Africa.

James Unam Monday, Dr., Department of Management and Accounting, Obafemi Awolowo University, Nigeria.

Udechukwu Ojiako, Professor, Faculty of Engineering and Information Technology, The British University in Dubai, Dubai. lend to large enterprises which are adjudged credit worthy in most of Africa. The commercial banks often avoid doing lending to small enterprises because of SMEs associated cost and relative high risk of operation (Aryeetey, 2008). This lack of access to credit to formal financial institutions necessitated the reforms in community banking that precipitated the licensing and establishment of microfinance institutions in Nigeria by the government through the Central Bank of Nigeria (CBN).

In 2005, the CBN commenced the process of reforms in the community banking sector. The latter resulted in the licensing of microfinance banks (MFBs), to replace community banks, with the goal of making MFBs more effective in granting credit to SMEs in order to develop this sector. Thus, private sector operators were statutorily empowered by the provisions of section 33 subsection (1) (b) of the CBN Act 7 of 2007 to operate MFBs in place of the community banks in Nigeria (CBN, 2008).

The CBN objective for the reform process that ushered the MFBs was to make it vehicles for social-economic growth and rural transformation through the provision of credit to SMEs. The intent was to reduce the burden of high interest rates and other financial charges hitherto charged by banks under normal bank lending, as well as to provide financial, advisory, technical and managerial supports to SMEs. The significant role expected of MFBs made the CBN to adopt it as the main source of funding for SMEs in Nigeria, especially those in the manufacturing sector. Manufacturing SMEs have a long gestation period, thus, the need for more accessible and cheap sources of finance especially long-term at affordable interest rates is a necessity (Abereijo and Fayomi, 2007, p. 127).

Notwithstanding these efforts by the CBN, many manufacturing SMEs are still shutting down operations due to liquidity problems and other related 
environmental business factors (Obokoh, 2011). The country is still ranked as $28^{\text {th }}$ poorest nation in the world with a low human development index (HDI) value of 0.511 and an unemployment level regrettably on the rise. This is partly due to the relatively under-developed manufacturing sector dominated by less intensive technology-driven operations compared to a number of sub-Saharan African countries such as South Africa, Kenya and Ghana (World Bank, 2009; HDR-UNDP, 2011). Recent studies in Nigeria and elsewhere confirmed some of the major causes of poor performance and the development of manufacturing SMEs in Nigeria to include financial constraint and lack of social supports (Oyefuga et al., 2008, p. 236).

This study, then, raises the question of how well has MFBs played their role of providing finance and social intermediation for SMEs since their creation by the CBN, and to what extent have they filled the credit gap in making credit accessible to SMEs? What innovative services have these MFBs introduced to aid the development of SMEs since their inception in Nigeria? In view of these, this study seeks to assess the extent to which MFBs have played its expected role of filling the credit constraint gap of SMEs towards their development in Nigeria. The study will also examine the various services rendered to manufacturing SMEs by MFBs; ascertain the process and procedures SMEs follow to access finance provided by MFBs and explore the challenges manufacturing SMEs face, if any in accessing MFBs finance.

Based on the questions, the study undertook the following objectives:

- Examine the financial and social intermediation for SMEs.

- Investigate the challenges in accessing finance from MFBs.

- Examine the process of accessing financing by SMEs.

- Determine the impact of MFBs' services on performance of manufacturing SMEs.

The study focuses on indigenous manufacturing SMEs operating within the formal sector for two key reasons. First, from a practical point, formality implies registration of the SME with a number of organizations, and most importantly, access to formal sources of finance. Secondly, although research (Rand and Torm, 2012) suggests that informal businesses make up a significant share of the SMEs population, Fajnzylber et al. (2009) claim that formalizing businesses can increase profits by at least $20 \%$. This study draws on Jackson et al. (2008) to define 'indigenous' in the context of entrepreneurship as referring to SMEs that operate predominant- ly in a local space, utilizing management practice that is either devoid of, or has been subjected to, limited influence by foreign business practices.

\section{Literature review}

1.1. SME access to finance. Some scholars have focused their study on the mechanism through which poverty can be reduced through SMEs activities. It is believed that access to finance enables the low income group overcome liquidity constraints and enable them undertake some level of investments to increase productivity (Hiedhues, 1995). According to Navajas et al. (2003, p. 750), the main objective of microcredit is to improve the welfare of the poor through better access to small loans that are not offered by the formal financial institutions.

SMEs access to finance is primarily a demand and supply function with, typically, research (Watson and Wilson, 2002; North et al., 2010; Mateev et al., 2013) on the demand-side focusing on understanding how characteristics of SMEs or their ownermanagers may be discerned in order to explain patterns of available and accessible finance. In terms of the characteristics and structure of most SMEs, studies (DeYoung et al., 2012; Mac and Bhaird, 2013) appear to indicate that risk diversification of asset composition also impacts upon SMEs access to finance. According to Nissanke (2001), the portfolio structure of most sub-Saharan SMEs is constrained, under-developed and insufficiently diversified; the implication being that losses in one business activity cannot necessarily be offset against gains in another activity. Manufacturing SMEs are also more likely to be in need of more accessible and cheap(er) sources of finance for a longer period than other types of SMEs (Chakrabarty and Bass, 2013).

Another finding from such studies (see Mateev et al., 2013) is the existence of a pecking order within SMEs. Pecking order theory proposes that cost associated with the funding of institutions will increase with asymmetric information (De Meza and Webb, 1987; Stiglitz and Weiss, 1981; Myers and Majluf, 1984; Watson and Wilson; 2002). In effect, pecking order theory suggests that SMEs will prioritise their sources of finance in the following hierarchical order: (1) internal sources of finance will be sought first. If such funding cannot be sourced or is sourced but, is, then, depleted, (2) debt will be taken on and when or if it becomes impractical to finance the institution using debt, (3) equity will be issued, usually as the last resort. Nikolaos et al's. (2013) study on Greek small businesses is in line with the pecking order theory. It was found that firms rely heavily on own funds due to reluctance making use of new external equity (venture capital, business angels, etc.). However, firms indicated preference for long-term debt 
equity in the absence of own funds if pressed to seek external funding which has a lot of limiting factor in accessing the long-term debt finance. Most of the Greek firms due to their size are unaware of state grants and co-financed programs because of informational gap of the existence of such programs.

On the supply side of SME access to finance, scholars (Soufani, 2001; Vos et al., 2007; Chimucheka and Rungani, 2011) appear to be interested in understanding how resource provision for SMEs may be enhanced through financial market efficiency. Here, the level of accessible finance for SMEs remains a function of how willing a financier is to lend (Vos et al., 2007), although it is also dependent on the actual demand for credit finance (Mach and Wolken, 2012). Chimucheka and Rungani (2011) found that about $28 \%$ of SMEs have never applied for loans from banks. Generally, studies show that SMEs continue to prefer internal equity as a source of funding (Mac an Bhaird and Lucey, 2010; McCann, 2011; BIS, 2012; Xiang et al., 2014), however, if unavailable or inadequate, most SMEs would seek external funding for their business activities. This is usually in the form of bank borrowing (Beck et al., 2008). Studies by Demirguc-Kunt et al. (2006) identify equity and debt as the two main sources of external finance for SMEs. However, the often lack of external equity on the supply side has meant that many SMEs depend on loans and overdrafts (from banks) and credit from their suppliers for financing. However, our understanding of the discourse is that an over-reliance on bank borrowing has left SMEs particularly vulnerable to contraction of private credit (Udell, 2009; Ullah et al., 2011). In response, governments have sought to increase SME access to finance by promoting a less conservative and riskaverse outlook among lenders (Quartey, 2003).

Although, technically, micro lending enables individuals from underprivileged social segments of society to establish enterprises (see Ayayi, 2012; Milana and Ashta, 2012), it can also involve the provision of financial and non-financial services to low-income SMEs owner-managers (Constantinou and Ashta, 2011; Woldie et al., 2012), particularly those involved in either indigenous or locally focused manufacturing. Such services may include social intermediation services such as group formation, development of self-confidence, and training in financial literacy and management capabilities among members of a group (Ngehnevu and Nembo, 2010). These social services, according to Han et al. (2014), help SMEs to alleviate the severity of their financial problems utilizing bank support and valuable advice which are good substitute for entrepreneurial human capital most SMEs lack.
In microfinance lending, timely repayments are an incentive for repeat credit facilities although in most cases no collateral is required (Ayayi, 2012; Baklouti, 2013). The implication is that MFBs are left with nothing in case of default as the micro-entrepreneurs are not capable of bearing bankruptcy costs (Newman et al., 2013), although access to finance increases risk-bearing abilities, while choice of microfinance lending (debt) is not influenced by risk aversion.

Despite the valuable contribution of microfinance banking to SME development, in reality, research (Adams and Pischke, 1992; Buckley, 1997; Coleman, 1999; Sodokin and Donou-Adonsou, 2010) is inconclusive on the actual contribution of microfinance to SMEs development and survival, thus, setting the scene for this study.

1.2. Manufacturing in Nigeria. As earlier indicated, the decision to focus the study on SMEs operating within Nigeria's manufacturing sector was partly driven by the transformational needs of the industry as articulated within its Vision 20: 2020 (see National Planning Commission, 2009). It is estimated that SMEs make up about $90 \%$ of Nigeria's manufacturing industry (World Bank, 2009), of which 31.4\% are indigenous (Asaolu et al., 2012). As enactors of innovation, SMEs are conceptualized as playing a major role in the transformation of the country's economy. Achieving success in such transformation is, however, facing considerable challenges, because, in comparison to the case in a number of sub-Saharan countries such as South Africa, Kenya and Ghana (Soderbom and Teal, 2002), manufacturing in Nigeria still remains relatively under-developed and dominated by less intensive technology-driven sectors such as food processing and textiles (World Bank, 2009); thus, its description by Adenikinju (2005, p. 14) as an industry "dominated by low wages, low technology, production of light consumer goods and resourceintensive and labour-intensive". Not surprisingly, the contribution of manufacturing to Nigeria's GDP continues to decline to about $0.05 \%$ in 2010 , from a peak in 1980 of about 11\% (Onyekwena, 2012). At the same time, production output has considerably declined (Tyler, 2002), while the average manufacturing capacity utilization which serves as a measure of manufacturing efficiency resides between $45 \%$ and $65 \%$ based on studies undertaken by the World Bank (2005; 2009) and Onuoha (2012).

\section{Methodology}

2.1. Outline of study area. This is a longitudinal study conducted in the Niger-Delta area, an oil-rich region of Nigeria. The Niger-Delta had over the years witnessed considerable environmental degra- 
dation, social disequilibrium and poverty due to decades of ambivalent social, economic and environmental policies, and violence (Bene et al., 2011; Ogundiya, 2011; Renouard and Lado, 2012; Pegg and Zabbey, 2013). The area accounts for over 95\% of Nigeria's export earnings (Davis, 2009), due to some factors, the Niger-Delta area remains impoverished and entrenched in youth restiveness.

The Niger-Delta region of Nigeria covers nine different states (provinces) within the country. The region is regarded as underdeveloped, characterized by crumbling social infrastructure and services, and pervasive and debilitating poverty (see UNDP, 2006; Amnesty International, 2009; Anugwom, 2011). It is estimated (see UNDP, 2006) that $70 \%$ of the inhabitants of the region live without basic facilities such as electricity, pipe-borne water, habitable housing or accessible roads. Data were collected from four states (provinces) within the Niger-Delta; Akwa Ibom, Bayelsa, Delta and Rivers States. The World Bank (2013) estimates the average poverty rates in these states ranges between $30 \%$ and $40 \%$.

2.2. The sample. Data were gathered in 2013 through random sampling of indigenous SMEs owner-managers in the Niger-Delta region crosslisted on the database of the Niger Delta Development Commission (NDDC), the Rivers State Microfinance Agency (RIMA) and the Akwa Ibom State Commission for Economic Development (AKCED). The NDDC database contained a list of SMEs which had benefitted directly from the US\$40 million Rural Finance Institution-Building Program (RUFIN), a program jointly funded by the Nigerian government, the Ford Foundation and other institutions that included the National MicroFinance Bank. We cross-checked this list against that of RIMA and AKCED in order to identify SMEs listed as (1) having not more than 49 staff and (2) focused on local manufacturing.

In total, over 800 of such indigenous SMEs were identified; however, data were collected from 300 respondents. The number of questionnaires collected reflects the difficulty with access in the Niger-Delta, due to ongoing violence that has continued in the region even with the signing of the Peace accord between the Nigerian government and militants (Joab-Peterside et al., 2012; Kew and Phillips, 2013). Research (Cohen and Arieli, 2011; Haer and Becher, 2012) acknowledges the difficult nature of obtaining data in conflict regions. In such environments, Faugier and Sargeant (1997) recommend the utilization of non-random purposive sampling. Here, the sampling objective was to focus on particular characteristics of the population of SMEs which was the interest of this study: in this case, the indigenous nature of the SMEs. For example, in homogeneous sampling, units are selected based on similar characteristics, because such characteristics are of particular interest to the researcher. In contrast, critical case sampling is frequently used in exploratory, qualitative research in order to assess (among other reasons) whether the phenomenon of interest even exists.

The decision to hand deliver the questionnaires was made based on our assessment of studies which report low response rates of web-based surveys (Fan and Yan, 2010; Mark et al., 2013). In addition, studies (see Greenlaw and Brown-Welty, 2009) that compare paper-based and web-based surveys found higher responses from paper-based surveys. We could not use online survey method due to the poor use of the internet by SMEs in Nigeria. Aleke et al. (2011) and Ojiako and Aleke (2011) suggest that ICT use by indigenous SMEs in Nigeria remains poor due to lack of understanding of the symbolic role of technology and its role as a communication facilitator. The view is supported by Jean et al's (2014) findings of poor ICT usage among SMEs in developing countries. A total of 16 copies of the questionnaires were discarded due to uncompleted or missing values and illegible completion. This left 284 questionnaires for analysis.

The questionnaire survey was supported by semistructured interview of 20 managers of selected MFBs, five from each of the four states under study and whose licenses from the CBN only allow them to operate at the state level. The reason for the qualitative method was to gain more understanding of the interaction between MFBs and SMEs in terms of the finance and intermediation services offered SMEs. This method enabled us analyze MFBs as a holistic entity, whose attributes we were able to scrutinize in full through a simultaneous analysis of SMEs and the managers responses. In addition, the qualitative interview revealed salient information which the quantitative method alone could not have expressed due to its restrictive nature (Shulha and Wilson, 2003). The interview result was analyzed using content analysis (Greene, 2005; Hsieh and Shannon, 2005).

2.3. The questionnaire. Data was collected using a survey instrument similar to Bloom and Van Reenan (2007) later expanded in 2010, which was structured using multiple response approach. The instrument has 18 questions, it was chosen as it is one of the few readily available survey instruments developed specifically for gathering empirical data on entrepreneurship management. We adjusted the questions slightly to focus on efficiencies in production processes and lending processes. Cronbach's coefficient Alpha of 0.725 confirmed the reliability of the analysis. The data collected were analyzed using frequency, percentage, and multiple regression analysis. 


\section{Results and discussion}

For clarity, the result is presented in two parts commencing with the questionnaire survey and, then, the interview.

3.1. Presentation of survey results. 3.1.1. Services rendered microfinance banks to SMEs. Table 1 shows that all the sampled SME owner-managers acknowledged being in receipt of either financial or social intermediation services from the MFBs. It was indicated by $44.0 \%$ that they were able to secured credit from MFBs which is contrary to Nikolaos et al. (2013) findings of Greek SMEs preference for own funds. The percentage of those who indicated they attended seminars organized by MFBs on how to manage their businesses was $29.2 \%$. The seminars we gathered during the interviews were a kind of mentorship programe for the SME owner-managers and the reason behind it will be made clearer during presentation of the interview results. Of the analyzed samples, $18.3 \%$ had been in receipt of business insurance cover. About $23.9 \%$ indicated to having received training and skills acquisition from the MFBs in financial literacy, while $16.9 \%$ indicated that they had received skills training in production and marketing.

The significance of microfinance institutions providing financial literacy training cannot be overemphasized, as the competency of SMEs owner-managers remains of critical importance not only noting the challenges faced by SMEs, but also the dominant role of SMEs owner-managers in decision making. SMEs may receive training administered either externally or in-house. It is, however, recommended (e.g., Bryan, 2006) that training (for example, in Health and Safety), which is non-industry- or sectorspecific may not necessarily be procured internally. The findings of Giagnocavo et al. (2012) and Han et al. (2014) suggest that social support from financial institutions represents a valuable contribution to entrepreneurial activity. In effect, the responses are in line with extant literature within the field of labor economics (see Fleisher et al., 2011) and developmental studies (see Mano et al., 2012) which highlights evidence of a positive relationship between training and both firm and human productivity.

Table1. Services rendered by microfinance banks

\begin{tabular}{|l|c|c|}
\hline \multicolumn{1}{|c|}{ Service } & Number of firms & Percentage \\
\hline Savings & 284 & 100.0 \\
\hline Credit/loans & 125 & 44.0 \\
\hline $\begin{array}{l}\text { Seminars on how to manage } \\
\text { business }\end{array}$ & 83 & 29.2 \\
\hline Training and skills acquisition & 68 & 23.9 \\
\hline Insurance cover & 52 & 18.3 \\
\hline $\begin{array}{l}\text { Seminars on health and } \\
\text { nutrition }\end{array}$ & 48 & 16.9 \\
\hline
\end{tabular}

Note: *Most SMEs have indicated more than one reason.
On examining preference for particular types of credit schemes, we found that the majority of SME ownermanagers sampled had secured predominantly shortterm finance (see Table 3), perhaps reinforcing the relationship between firm size and access to finance (Ezeoha, 2008; Xiang et al., 2014). This is contrary to the findings of Nikolaos et al. (2013) where Greek SMEs rely heavily on their own funds and would not raise new equity from sources outside their family. The common grounds of this study with Nikolaos et al (2013) findings is the difficulty and limitations of assess to long-term debt financing for SMEs. Although, Abereijo and Fayomi (2007, p. 137) recommend that long term financing is most suitable for manufacturing SMEs, since they have a long gestation period that can extend to several years. The lack of long term funding prevents a potential mismatch between project gestation and loan maturity for manufacturing SMEs.

3.2. Challenges in accessing finance from microfinance banks. In terms of the distribution of respondent firms by challenges facing SMEs in securing finance from the MFBs (Table 2), it was observed that cumbersome processes $(72.11 \%)$ and inadequate information about the activities of microfinance lenders (38.37\%) served as major limiting factors towards securing finance from micro-lenders. The result is consistent with Abereijo and Fayomi (2007, p. 134) findings on venture capital finance for SMEs in Nigeria, it was discovered that a high proportion of the SMEs were sole proprietorships (family business) whose business capital were mainly from personal savings, loans from relatives/friends, cooperatives and banks, especially MFBs. The result also revealed that size adversely affected their chance of securing credits. This is in line with the findings of Ngehnevu and Nembo (2010) who also found that the size of businesses were a big determinant in securing finance from microfinance institutions in Cameroon.

Table 2. Challenges faced by SMEs in accessing finance from MFBs

\begin{tabular}{|l|c|}
\hline \multicolumn{1}{|c|}{ Challenges } & Percentage \\
\hline Cumbersome process/requirements & 72.11 \\
\hline Inadequate information about services of MFBs & 38.37 \\
\hline Short repayment period & 30.02 \\
\hline Nepotism and favoritism & 17.35 \\
\hline Bribery & 4.91 \\
\hline
\end{tabular}

Note: *Most SMEs have indicated more than one reason.

Other factors identified by the respondents as undermining their ability to secure access to funding included short payback periods $(30.02 \%)$, and unsurprisingly - corruption (nepotism, $17.35 \%$; bribery, 4.91\%). Mambula (2002, p. 63) study also found similar situation that loans based on nepotism and favoritism were a common practice in Nigeria which needed be tackled with zero tolerance. 
3.3. Process of accessing finance by SMEs. The results of the analysis further reveal that although there is the availability of microcredit financing for SMEs, but the processes and procedures for acessing these funds constitute a stumbling block. Based on our analysis in Table 3, majority $(73.8 \%)$ of the respondent firms indicated that the processes and procedures for accessing the credits from the banks were very cumbersome, especially for start-up businesses. This is because MFBs require guarantor(s) who have securable assets, salary earners of the banks or receive their salaries through the banks. These, in most cases, posed serious obstacles, as there were very few manufacturing SMEs, especially the start-ups that could meet these requirements. This adversely affects the client base of the banks and the development of SMEs in Nigeria. About $23.6 \%$ of the firms indicated that the process was simple (no strict guarantor conditions), but with long lead time - the period between when the application and delivery of financing services. However, a few of the SMEs, about $2.8 \%$, indicated that the process was simple to obtain loans from the banks, and the lead time was also short.

3.4. Services of MFBs and performance of manufacturing SMEs. Regression analysis was employed to investigate the impact of the microfinance banks' services on the performance of the SMEs. Using stepwise regression, financial and social intermediation services were used as the independent variables, while the dependent variable was the financial performance which was measured by the return on investment of the firms (Table 2). To measure the goodness of fit of the regression, the adjusted coefficient of multiple determination $\left(R^{2}\right)$ was used. Our findings revealed that the services of MFBs had significantly impact on the profitability of SMEs in Nigeria $(F=82.165, p<0.05)$. The high adjusted $R^{2}$ value (0.603) indicated that the services of MFBs were sufficient to explain as high as $60 \%$ of the performance of the SMEs. This implied a positive relationship between the services of MFBs and the performance of manufacturing SMEs. The result of the Durbin Watson was satisfactory $(\approx 2)$, indicating no autocorrelation between the residuals from the regression model.

The analysis further showed that only the financial services rendered by the banks had significant influence on the profitability performance of the firms $(t=$ $9.322, p<0.05)$. The reason for this could be traced to the weak performance of the MFBs in terms of provision of social intermediation services which effectively boost the management capabilities of the manufacturing SMEs. Management capability plays a vital role in the development of SMEs, including access to finance. Poor management capabilities and practice has been identified by several studies (see Akanji, 2006, p. 100; Aleke et al., 2011; Okpara, 2011) as one of the factors that limit SMEs development in Nigeria.

This shortfall in management capabilities evidently reveals a dire need for training and education for entrepreneurs in financial management, business plan preparation, proposal writing, project planning and evaluation. Thus, Nigerian government should pay special attention to the development of management capabilities of SMEs, especially the manufacturing SMEs. This supports Smorfitt's (2005) study that found management development to be the third largest contributing factor to Ireland's phenomenal economic growth of $10 \%$ from 1994 to 2000 .

Table 4. Multiple regression of the impact of the services of microfinance banks on SMEs' performance

\begin{tabular}{|l|c|c|c|c|}
\hline \multicolumn{1}{|c|}{ Independent variable } & Beta & s.e & $t$ & Sig, \\
\hline Constant & 0.996 & 0.128 & 7.776 & 0.000 \\
\hline Financial services & 0.396 & 0.042 & 9.322 & 0.000 \\
\hline Social services & 0.047 & 0.035 & 1.337 & 0.184 \\
\hline Multiple R & 0.781 & & F & 82.165 \\
\hline R-square & 0.610 & & Sig. (F-statistic) & 0.000 \\
\hline Adjusted R-square & 0.603 & & Durbin Watson & 2.016 \\
\hline Standard Error of Estimate & 0.416 & & & \\
\hline
\end{tabular}

Note: dependent variable: financial performance.

4.2. Presentation of interview response. On the other hand, the interview with the managers of the MFBs revealed certain shortcomings on the part of the manufacturing SMEs that make it difficult for them to access finance from the banks. They are:

- Poorly packaged business plan/proposal: The inability of SMEs to engage professionals and the shortage of skilled manpower to prepare accepta- ble plan business is one of the critical constraints inhibiting access to MFBs credits and the development of SMEs in Nigeria. This was also found in Ekpenyong and Nyong (1992), Oyefuga et al. (2008, p. 241). Thus, putting up an attractive business plan is a daunting challenge for the SMEs.

- Unreliable accounting information: There is difficulty in obtaining accurate information on 
the financial performance of SMEs due to poor and unreliable financial records. This makes financial review of the activities of the SMEs by the banks tough, hence, appropriate basis for loans decision is completely lacking.

- Defaults: Many of the SMEs finds it difficult to promptly repay their debts due to the Nigeria's unfavorable business environment coupled with the poor state of infrastructure, particularly public power supply. Most of the manufacturing SMEs result in self-provision power which greatly increases their operating costs and adversely affects their profits. The power supply problem is an external factor which most SMEs do not envisage would cut down on their profits and, hence, affect their ability to promptly service their loans. As was indicated by Ayayi (2012) and Baklouti (2013), in microfinance lending, timely repayments are an incentive for repeat credit facilities.

- Lack of trustworthy guarantors: Most of the guarantors presented by the SMEs cannot be trusted and do not meet the bank's requirements. This makes it difficult for the SMEs to obtain credit facilities, as the guarantors are not acceptable by the banks either due to their poor financial standing with the banks or do not have their salary accounts domicile in the bank.

Other key findings from the interview on MFBs are:

- Mentorship: The MFBs provide mentorship in form of close monitoring and guidance of the activities of those SMEs they granted credits beside training and seminars organized for SMEs. The reason is to ensure that MFBs client businesses do not run into problems, because the mentorship activity helps to guarantee the repayment of the line of credit extended to SMEs clients. This enables early detection of distress by the microfinance bank for appropriate action such as cancellation of line of credit or providing additional support to remedy the challenge of the SMEs concerned.

- Small size of the microfinance bank capital base: The capital bases of MFBs are still very small compared to commercial banks. This is one of the main reasons MFBs are unable to grant long term credits to SMEs. The general belief, as stated by some of the managers, is need to spread their available funds to their credit worthy customers on short term credits. For instance, the CBN in June 2011 fixed the minimum capital requirement for those MFBs operating at the national level to be NGN 2 billion (USD 12.8 million), while capital base of those operating at the regional level is NGN 100 million (USD 640,000) from earlier fixed NGN 1 billion (USD 6.4 million), and those operating at the rural level, with one branch re- mains at NGN 20 million (USD 128,000). This capital base obviously cannot sustain medium term loans let alone long term loans to MFBs clients.

- In 2010, the CBN revoked the operating licenses of 224 MFBs out of the 820 operating in the country, because they were described as "terminally distressed and technically insolvent". The CBN listed other factors that contributed to the unsoundness of the MFBs as high level of non-performing loans that resulted in high risk portfolios and impaired capital base, gross under-capitalization in relation to level of operations, poor corporate governance and incompetent boards.

\section{Conclusion and recommendation}

The objective of this study was to assess if microfinance lending ease SMEs' access to finance in Nigeria and, therefore, seek to facilitate our understanding of the challenges of SMEs access to finance in developing countries. Although our results showed that MFBs has contributed to the performance and development of indigenous manufacturing SMEs in Nigeria, the results was limited by low response rate, because it was undertaken in the Niger-Delta, an area associated with an overarching level of poverty, illiteracy and youth restiveness. We believe this accounted for the rather low response rate of the survey.

However, despite MFB's significant contribution to SMEs' access to finance and development, there is still shortfall in the social intermediation services of MFBs, as many SMEs were denied access to finance due to unattractive business plan/proposal, and lack of proper accounting information. To adequately tackle the problem of poor management capabilities, there should be alliance of MFBs and research institutions to provide relevant training to entrepreneurs in the art of financial management, business plan preparation and proposal. Also, MFBs should be subsidized to educate SMEs manager-owners on current business issues and information on current market trends, products, and equipment through public enlightenment and seminars.

In addition to providing social intermediation, the guidelines on MFBs should be flexible in order to accommodate more SMEs which would eventually help to combat the menace of unemployment and youth restiveness in the country. Considering the challenge of high interest rates, the government should provide intervention funds to enable MFBs draw from it for long term loans disbursement to SMEs. The intervention funds would also help MFBs to extend the repayment period granted to manufacturing SMEs. The legal and regulatory frame work in Nigeria should be strengthened to ensure zero tolerance to the practice of loans disbursement based on nepotism, favoritism, and bribery. 


\section{References}

1. Abereijo, I.O. and Fayomi, A.O. (2007). The Attitude of Small and Medium Industrialists to Venture Capital Financing in Nigeria, Global Journal Of Business Research, 1 (1), pp. 127-138.

2. Adams, D. and Picshke, J.D. (1992). Microenterprise Credit Programs: Déjà vu, World Development, 20, pp. 1463-1470.

3. Adenikinju, A. (2005). Productivity Performance in Developing Countries, in UNIDO (Ed), Foreign direct investment and productivity: evidence from the East Asian economies United Nations Industrial Development Organisation.

4. Adomi, Esharenana E., Ayo, Blessing T. and Nakpodia, E.D. (2007). A Better Response Rate for Questionnaires: Attitudes of Librarians in Nigerian University Libraries, Library Philosophy and Practice (e-journal) Paper 154. Available at: http://digitalcommons.unl.edu/libphilprac/154, (accessed 19 February 2014).

5. Akanji, O.O. (2006). Microfinance as a strategy for poverty reduction, Central Bank of Nigeria Economic and Financial Review, 39 (4), pp. 98-112.

6. Aleke, B., Ojiako, G.U. and Wainwright, D. (2011). Social Networks among Small Agribusinesses in Nigeria, Society and Business Review, 6 (3), pp. 214-228.

7. Alvarez, S. and Barney, J. (2014). Entrepreneurial Opportunities and Poverty Alleviation, Entrepreneurship Theory and Practice, 38 (1), pp. 159-184.

8. Amnesty International (2009). Petroleum, Pollution and Poverty in the Niger Delta. Pub. Amnesty International. Available at: http://www.amnesty.org/en/library/asset/AFR44/017/2009/en/e2415061-da5c-44f8-a73c-a7a4766 ee21d/afr440172009en.pdf, (accessed 19 February 2014).

9. Anugwom, E.E. (2011). Wetin We for Do? Women Entrepreneurs and the Niger Delta Conflict, Journal of Small Business and Entrepreneurship, 24 (2), pp. 243-252.

10. Aryeetey, E. (2008). From Informal Finance to Formal Finance in Sub-Saharan Africa: Lessons from Linkage Efforts. Paper Presented at the High-Level Seminar on African Finance for the 21st Century Organized by the IMF Institute and the Joint Africa Institute Tunis, Tunisia, March 4-5.

11. Asaolu, T.O., Agorzie, C.J. and Monday, J.U. (2012). Materials Management: An Effective Tool for Optimizing Profitability in the Nigerian Food and Beverage Manufacturing Industry, Journal of Emerging Trends in Economics and Management Sciences, 3 (1), pp. 25-31.

12. Ayayi, A. (2012). Micro-Credit and Micro-Equity: The David and the Goliath of Micro-Enterprise Financing, Economic Papers, 31 (2), pp. 244-254.

13. Baklouti, I. (2013). Determinants of Microcredit Repayment: The Case of Tunisian Microfinance Bank, African Development Review, 25 (3), pp. 370-382.

14. Beck, T., Demirgüç-Kunt, A. and Singer, D. (2013). Is Small Beautiful? Financial Structure, Size and Access to Finance, World Development, 52, pp. 19-33.

15. Bene, C., Evans, L., Mills, D., Ovie, S., Raji, A., Tafida, A., Kodio, A., Sinaba, F., Morand, P., Lemoalle, J. and Andrew, N. (2011). Testing Resilience Thinking in a Poverty Context: Experience from the Niger River Basin, Global Environmental Change, 21 (4), pp. 1173-1184.

16. Bloom, N. and Van Reenen, J. (2007). Measuring and Explaining Management Practices Across Firms and Countries, The Quarterly Journal of Economics, 122 (4), pp. 1351-1408.

17. Bryan, J. (2006).Training and Performance in Small Firms, International Small Business Journal, 24 (6), pp. 635-660.

18. Buckley, G. (1997). Microfinance in Africa: Is it either a Problem or the Solution? World Development, 25 (7), pp. 1081-1093.

19. Burns, R.B. (2000). Introduction to Research Methods, 4th Edition. New Delhi: SAGE Publications Ltd.

20. Central Bank of Nigeria. (2008). Annual Report and Statement of Accounts. Central Bank of Nigeria, Abuja.

21. Chakrabarty, S. and Bass, A. (2013). Encouraging Entrepreneurship: Microfinance, Knowledge Support, and the Costs of Operating in Institutional Voids, Thunderbird International Business Review, 55 (5), pp. 545-562.

22. Chimucheka, T. and Rungani, E.C. (2011). The Impact of Inaccessibility to Bank Finance and Lack of Financial Management Knowledge to Small, Medium and Micro Enterprises in Buffalo City Municipality, South Africa, African Journal of Business Management, 5 (14), pp. 5509-5517.

23. Cohen, N. and Arieli, T. (2011). Field Research in Conflict Environments: Methodological Challenges and Snowball Sampling, Journal of Peace Research, 48 (4), pp. 423-435.

24. Coleman, B.C. (1999). The Impact of Group Lending in North East Thailand, Journal of Development Economics, 60 , pp. $105-141$

25. Constantinou, D. and Ashta, A. (2011). Financial Crisis: Lessons from Microfinance, Strategic Change, 20 (5-6), pp. 187-203.

26. Davis, S. (2009). The Opportunity for Peace in the Niger Delta, GEEI Green Paper Series, No. 2, Summer. Available at: www.geei-sais.org (Accessed 12 April 2011).

27. De Meza, D. and Webb, D.C. (1987). Too Much Investment: A Problem of Asymmetric Information, The Quarterly Journal of Economics, 102, pp. 281-292.

28. Demirguc-Kunt, A., Maksimovic, V., Beck T. and Laeven, L. (2006). The Determinant of Financing Obstacles, Journal of International Money and Finance, 25 (6), pp. 932-952. 
29. Department for Business and Skills (BIS) (2012). SME Access to External Finance, BIS Economics paper no. 16, London. Available at: http://www.bis.gov.uk/assets/BISCore/enterprise/docs/S/12-539-sme-access-external-finance.pdf (Accessed 03 June 2011).

30. DeYoung, R., Gron, A., Torna, G. and Winton, A. (2012). Risk Overhang and Loan Portfolio Decisions: Small Business Loan Supply Before and During the Financial Crisis. Available at: http://ssrn. com/abstract, 2140952.

31. Ekpenyong, D.B. and Nyong, M.O. (1992), Small and Medium Enterprises in Nigeria: Their Characteristics, problems and Sources of Finance, AERC Research Paper 16, African Economic Research Consortium, Nairobi.

32. Ezeoha, A. (2008). Firm Size and Corporate Financial-Leverage Choice in a Developing Economy: Evidence from Nigeria, Journal of Risk Finance, 9 (4), pp. 351-364.

33. Fajnzylber, P., Maloney, W.F. and Montes-Rojas, G. (2009). Releasing Constraints to Growth or Pushing on a String? Policies and Performance of Mexican Micro-Firms, Journal of Development Studies, 45 (7), pp. 1027-1047.

34. Fan, W. and Yan, Z. (2010). Factors Affecting Response Rates of the Web Survey: a Systematic Review, Computers in Human Behaviour, 26 (2), pp. 132-139.

35. Faugier, J. and Sargeant, M. (1997). Sampling Hard to Reach Populations, Journal of Advanced Nursing, 26, pp. 790-797.

36. Fleisher, B. M., Hu, Y., Li, H. and Kim, S. (2011). Economic Transition, Higher Education and Worker Productivity in China, Journal of Development Economics, 94 (1), pp. 86-94.

37. Giagnocavo, C., Gerez, S. and Sforzi, J. (2012). Cooperative Bank Strategies for Social-Economic Problem Solving: Supporting Social Enterprise and Local Development, Annals of Public and Cooperative Economics, 8(3), pp. 281-315.

38. Greene, J.C. (2005). Synthesis: A Reprise on Mixing Methods. In T.S. Weisner (Ed.), Discovering Successful Pathways in Children's Development: Mixed Methods in the Study of Childhood and Family Life. Chicago: University of Chicago Press, pp. 405-419.

39. Greenlaw, C. and Brown-Welty, S. (2009). A Comparison of Web-Based and Paper Based Survey Methods: Testing Assumptions of Survey Mode and Response Cost, Evaluation Review, 33(5), pp. 464-480.

40. Haer, R., and Becher, I. (2012). A Methodological Note on Quantitative Field Research in Conflict Zones: Get your Hands Dirty, International Journal of Social Research Methodology, 15 (1), pp. 1-13.

41. Han, L., Benson, A., Chen, J.J. and Zhang, S. (2014). The Use and Impacts of Bank Support on UK Small and Medium-Sized Enterprises, International Small Business Journal, 32 (1), pp. 61-80.

42. Heidhues, F. (1995). Rural Finance Markets-An Important Tool to Fight Poverty, Quarterly Journal of International Agriculture, 34 (2), pp. 105-108.

43. Hsieh, H. and Shannon, S.E. (2005). Three Approaches to Qualitative Content Analysis Qualitative Health Research, 15 (9), pp. 277-1288.

44. Human Development Report (2011). Statistical Annex. New York: United Nations Development Programmes.

45. Jackson, T., Amaeshi, K. and Yavuz, S. (2008). Untangling African Indigenous Management: Multiple Influences on the Success of SMEs in Kenya, Journal of World Business, 43 (3), pp. 400-416.

46. Jean D. Kabongo, John O. Okpara. (2014). ICT Possession among Congolese SMEs: An Exploratory Study, Journal of Small Business and Enterprise Development, 21 (2), pp. 313-326.

47. Joab-Peterside, S., Porter, D. and Watts, M. (2012). Rethinking Conflict in the Niger Delta: Understanding Conflict: Dynamics, Justice, and Security, United States Institute of Peace, pp. 1-33.

48. Kew, D. and Phillips, D.L. (2013). Seeking Peace in the Niger Delta: Oil, Natural Gas, and Other Vital Resources, New England Journal of Public Policy, 24 (1), p. 12.

49. Mac an Bhaird, C. and Lucey, B. (2010). Determinants of Capital Structure in Irish SMEs, Small Business Economics, 35 (3), pp. 357-375.

50. Mach, T. and Wolken, J. (2012). Examining the impact of credit access on small firm survivability. Finance and Economics discussion series Washington D.C: Divisions of Research and Statistics and Monetary Affairs, Federal Reserve Board.

51. Mambula, C. (2002). Perception of SME Growth Constraints in Nigeria, Journal of Small Business Management, 40 (1), pp. 58-65.

52. Mano, Y., Iddrisu, A., Yoshino, Y. and Sonobe, T. (2012). How Can Micro and Small Enterprises in Sub-Saharan Africa Become More Productive? The Impacts of Experimental Basic Managerial Training, World Development, 40 (3), pp. 458-468.

53. Mark D., Pauric, M. and Niall, M. (2013), Exploring Social Media Adoption in Small to Medium-Sized Enterprises in Ireland, Journal of Small Business and Enterprise Development, 20 (4), pp. 716-734.

54. McCann, F. (2011). Access to Credit Amongst SMEs: Pre and Post-crisis Evidence from Eastern Europe. Central Bank of Ireland: Economic Letter Series, 2011, 3.

55. Milana, C. and Ashta, A. (2012). Developing Microfinance: A Survey of the Literature, Strategic Change, 21 (78), pp. 299-330.

56. National Planning Commission (2009). Nigeria Vision 20:2020 Economic Transformation Blueprint. The Presidency: Abuja.

57. Navajas, S., Conning, J. and Gonzalez-Vega, C. (2003). Lending Technologies, Competition and Consolidation in the Markets for Microfinance in Bolivia, Journal of Institutional Development, 15, pp. 747-770. 
58. Newman, A., Borgia, D. and Deng, Z. (2013). How Do SMEs with Single and Multiple Owners Finance Their Operations Differently? Empirical Evidence from China, Thunderbird International Business Review, 55 (5), pp. 531-544.

59. Ngehnevu, C.B. and Nembo, F.Z. (2010). The Impact of Microfinance Institutions (MFIs) in the Development of Small and Medium Size Businesses (SMEs) in Cameroon: A case study of CamCCUL, Published Master's Thesis in Business Administration, Swedish University of Agricultural Sciences.

60. Nikolaos, D., Robin, J. and Emmanouil, S. (2013). Financing Practices and Preferences for Micro and Small Firms, Journal of Small Business and Enterprise Development, 20 (1), pp. 80-101.

61. Nissanke, M. (2001). Financing Enterprise Development in Sub-Saharan Africa, Cambridge Journal of Economics, 25 (3), pp. 343-367.

62. Normah, M.A. (2006). SMEs: Building Blocks for Economic Growth, Paper Presented at the National Statistics Conference, Kuala Lumpur, Malaysia, 4-5 September, pp. 1-13.

63. Obokoh, L.O. (2008). Small and Medium Sized Enterprises Development under Trade Liberalization: A Survey of Nigerian Experience, International Journal of Business and Management, 3 (12), pp. 92-101.

64. Obokoh, L.O. (2011). Capital Account Liberalisation: Has It Improved SMEs Situation in Nigeria? International Journal of Business and Emerging Markets, 3 (4), pp. 337-395.

65. Ogundiya, I.S. (2011). Beyond the 'Geography of Terrorism and Terror of Geography' Thesis Corruption and the Development Tragedy in the Niger Delta Region, Journal of Developing Societies, 27 (1), pp. 57-91.

66. Ojiako, G.U. and Aleke, B. (2011). Symbols as Cultural Expressions of Technology Diffusion, Society and Business Review, 6 (3), pp. 198-213.

67. Okpara, J. (2011). Factors Constraining the Growth and Survival of SMEs in Nigeria: Implications for Poverty Alleviation, Management Research Review, 34 (2), pp. 156-171.

68. Onuoha, B. (2012). The Environments of the Manufacturing Sector in Nigeria: Strategies Towards Vision 2020, International Business and Management, 5 (1), pp. 67-74.

69. Onyekwena, C. (2012). Empirical Investigation of the Impact of Foreign Direct Investment on Manufacturing Firms and Banks in Nigeria, Unpublished PhD Thesis, University of Portsmouth.

70. Oyefuga, I.O., Siyanbola, W.O., Afolabi, O.O., Dada, A.D. and Egbetokun, A.A. (2008). SMEs Funding: An Assessment of an Intervention Scheme in Nigeria, World Review of Entrepreneurship, Management and Sustainable Development, 4 (2/3), pp. 233-245.

71. Pegg, S. and Zabbey, N. (2013). Oil and Water: the Bodo Spills and the Destruction of Traditional Livelihood Structures in the Niger Delta, Community Development Journal, 48 (3), pp. 391-405.

72. Quartey, P. (2003). Financing Small and Medium Enterprises (SMEs) in Ghana, Journal of African Business 4 (1), pp. 37-55.

73. Rand, J. and Torm, N. (2012). The Benefits of Formalization: Evidence from Vietnamese Manufacturing SMEs, World Development, 40 (5), pp. 983-998.

74. Renouard, C., and Lado, H. (2012). CSR and Inequality in the Niger Delta (Nigeria), Corporate Governance, 12 (4), pp. 472-484.

75. Shkolnikov, A. and Sullivan, J.D. (2010). Meeting the Institutional Challenges of the Millennium Development Goals, Development, 53 (1), pp. 58-63.

76. Soufani, K. (2001). The Role of Factoring in Financing UK SMEs: a Supply Side Analysis, Journal of Small Business and Enterprise Development, 8 (1), pp. 37-46.

77. Soderbom, M. and Teal, F. (2002). The Performance of Nigerian Manufacturing Firms: Report on the Nigerian Manufacturing Enterprise Survey 2001. Centre for the Study of African Economies.

78. Sodokin, K. and Donou-Adonsou, C. (2010). Banks, Microfinance Institutions and Economic Growth in the West African Economic and Monetary Union, African Development Review, 22 (4), pp. 495-510.

79. Sriram, V. and Mersha, T. (2010). Stimulating Entrepreneurship in Africa, World Journal of Entrepreneurship, Management and Sustainable Development, 6 (4), pp. 257-272.

80. Stiglitz, J. E. and Weiss, A. (1981). Credit Rationing in Markets with Imperfect Information, The American Economic Review, 71, pp. 393-410.

81. Tyler, G. (2002), Nigeria - Public and Private Electricity Provision as a Barrier to Manufacturing Competitiveness. Available at: World Bank. https://openknowledge.worldbank.org/handle/10986/9746. Accessed 16 February, 2014.

82. Udechukwu, F.N. (2003). Survey of Small and Medium Scale Industries and their Potentials in Nigeria, in: Central Bank of Nigeria (CBN) Seminar No. 4, Small and Medium Industries Equity Investments Scheme (SMIEIS), Training Centre, Lagos, No. 4, pp. 1-14.

83. Udell, G. (2009). How will a Credit Crunch Affect Small Business Finance? Federal Reserve Bank of San Francisco Economic Letter, 2009-09.

84. Ullah, F., North, D. and Baldock, R. (2011). The Impact of the Financial Crisis on the Financing and Growth of Technology-Based Small Firms in the United Kingdom. London: ISBE Rake Fund.

85. UNDP. (2006). Niger Delta Human Development Report. Abuja: Nigeria UNDP.

86. United Nations Development Programme, Evaluation Office. (1999). Essentials on Microfinance. New York: One United Nations Plaza.

87. United Nations Economic Committee for Europe (UNECE). (2003). Small and Medium-Sized Enterprises in Countries in Transition. United Nations, New York and Geneva: Entrepreneurship and SMEs. 
88. Vos, E., Jia-Yuh Yeh, A., Carter, S. and Tagg, S. (2007). The Happy Story of Small Business Financing, Journal of Banking and Finance, 31 (9), pp. 2648-2672.

89. Watson, R. and Wilson, N. (2002). Small and Medium Size Enterprise Financing: A Note on Some of the Empirical Implications of a Pecking Order, Journal of Business Finance and Accounting, 29 (3-4), pp. 557-578.

90. Woldie, A., Mwita, J. and Saidimu, J. (2012). Challenges of Microfinance Accessibility by SMEs in Tanzania, Thunderbird International Business Review, 5 (44), pp. 567-579.

91. World Bank. (2009). An Assessment of the Investment Climate in Nigeria. Available at: http://documents.worldbank.org/curated/en/2009/01/10360490/assessment-investment-climate-nigeria. Accessed 17 February 2014.

92. World Bank (2013). Nigeria Economic Report. Available at: http://documents.worldbank.org/curated/en /2013/05/17708026/nigeria-economic-report. Accessed 17 February 2014.

93. Xiang, D., Worthington, A.C. and Higgs, H. (2014). Discouraged Finance Seekers: An Analysis of Australian Small and Medium-Sized Enterprises, International Small Business Journal, doi: 10.1177/0266242614534281. 